\title{
MEDIA SOSIAL DAN PENGARUHNYA TERHADAP AKHLAK MAHASISWA DI KOTA METRO
}

(Menilik Penggunaan Media Sosial di Perguruan Tinggi Agama Kota Metro Lampung)

\author{
Oleh: \\ Aprina Chintya \\ Universitas Islam Negeri Sunan Kalijaga Yogyakarta \\ Email: aprinachintya64@gmail.com
}

\author{
Latifatul Khoiriyah \\ Institut Agama Islam Negeri Metro Lampung \\ Email: latifatul_khoiriyah27@ymail.com
}

\begin{abstract}
Social media on the one hand brings a positive impact for students. But, on the other hand, it's brings a negative impact if users are not selective and wise in use it. Abuse of the use of social media causes the decline of morals on the students. This study aims to see the influence of social media on morality students in Metro City. This research is field research, conducted at State Islamic Institute (IAIN) Metro, Ma'arif Institute of Islam (IAIM) Nahdatul Ulama Metro and Muhamadiyah Metro University. Primary data source is done by interview to student and secondary data source obtained by conducting literature study. Data analysis is done from the beginning to the end of the research with triangulation of data. Furthermore, data analysis results are described in the discussion. The result show that the high intensity of social media users (social networking) on students in Metro City affect the morals of students, both the influence of negative and negative. Therefore, students must be selective and wise in order to utilize social media only for positive things.
\end{abstract}

Keywords: Social Media, Morals, Social Networking, Student 


\section{A. PENDAHULUAN}

Internet merupakan sesuatu hal yang sudah tidak asing lagi bagi masyarakat modern Indonesia. Tentu masyarakat masih mengingat bahwa sebelumnya teknologi internet hanya digunakan untuk mengirim pesan elektronik melalui email dan chatting, untuk mencari informasi melalui browsing, dan searching. Namun saat ini, seiring dengan perkembangannya, internet mampu melahirkan suatu jaringan baru yang bisa dikenal dengan sebutan media sosial. Sebagaimana yang diketahui, media sosial merupakan media online dimana para penggunanya dapat ikut serta dalam mencari informasi, berkomunikasi, dan menjaring pertemanan, dengan segala fasilitas dan aplikasi yang dimiliki seperti blog, facebook, dan twitter. ${ }^{1}$

Melalui internet, segala informasi dapat diketahui dan juga bisa dijadikan sebagai tempat bisnis. Perlu diketahui oleh para pengguna internet bahwa internet seperti halnya sebuah pisau, internet akan menjadi sangat fatal bagi penggunanya jika tidak mengetahui teknik pemanfaatan dan penggunaannya dengan baik dan benar. ${ }^{2}$

Akan tetapi tanpa disadari atau tidaknya, perlahanlahan internet akan mengubah pola akhlak para penggunanya. Penyalahgunaan internet akan

${ }^{1}$ Novia Ika Setyani, "Penggunaan Media Sosial Sebagai Sarana Komunukasi bagi Komunitas: Study Deskriptif Penggunaan Media Sosial Twitter, Facebook, dan Blog Sebagai Sarana Komunikasi bagi Komunitas Akademi Berbagi Surakarta", (Program Study

2 Donny B.U.Usir Galau Dengan Internet Sehat.(Yogyakarta:Andi Ofset,2013),h.1 dikutip dari skripsi lina aprilia, Fakultas Agama IslamUniversitas Muhammadiyah Surakarta; pengaruh Internet terhadap akhlak siswa kelas XI SMAN 1 Jatisrono, 2014, h, 1

Media sosial dan pengaruhnya terhadap.... 
menyebabkan keruntuhan akhlak pada golongan remaja khususnya dimasa kini. Internet saat ini bukan hanya penyebab keruntuhan akhlak remaja, namun juga telah mewabah pada golongan pelajar siswa, mahasiswa bahkan pekerja kantoran.

Hal ini diungkapkan oleh Wan Norina Wan Hamat, et.al:

"Media massa banyak memberi perkembangan dan maklumat kepada masyarakat terutamanya berkaitan hal ehwal semasa, berita luar mahupun dalam negara. Media turut memberi manfaat kepada perkembangan pendidikan masa kini. Namun dalam masa yang sama media massa juga mungkin menyumbang ke arah kesan negatif. Salah satu penyebab berlakunya keruntuhan akhlak remaja masa kini adalah hasil dari pada bahan dan rancangan media massa yang dipaparkan dalam negara." 3

Berdasarkan hal di atas, terlihat bahwa media massa memiliki dampak positif dan juga negatif. Demikian halnya juga pada media sosial yang saat ini tengah berkembang dan banyak digunakan oleh mahasiswa. Sebagai generasi penerus bangsa, mahasiswa tentu harus harus selektif dan bijak dalam menggunakan media sosial. Tidak dapat dipungkiri bahwa media sosial memiliki dampak positif dan negatif yang berdampak pada akhlak mahasiswa. Oleh sebab itu, penelitian ini penting karena akan mengulas tentang pengaruh penggunaan media sosial terhadap akhlak mahasiswa di Perguruan Tinggi Agama Kota Metro.

Penelitian ini adalah penelitian lapangan (field research), yang dilakukan di Institut Agama Islam Negeri (IAIN) Metro, Institut Agama Islam Ma'arif (IAIM)

${ }^{3}$ Wan Norina Wan Hamat, et.al, Pengaruh Media Massa Terhadap Penampilan Akhlak Pelajar Islam Politeknik Malaysia, dalam The Online Journal of Islamic Education January 2013, Vol. 1 Issue 1, Universitas Malaysia, h. 17

Media sosial dan pengaruhnya terhadap.... 
Nahdatul Ulama Metro dan Universitas Muhamadiyah Metro. Sumber data dalam penelitian ini dikategorikan dalam dua kelompok besar: Pertama, sumber data primer, yaitu data yang diperoleh secara langsung dari subyek penelitian. Terkait dengan data penelitian, peneliti melakukan wawancara (interview) dengan mahasiswa dengan kriteria aktif menggunakan media sosial. Kedua, sumber data sekunder, yaitu diperoleh dengan melakukan studi literatur. Analisa data dilakukan bersamaan dengan dimulainya pengumpulan data secara terus menerus sampai pada akhir penggumpulan data. Kemudian data dianalisa kembali serta dilakukan triangulasi dari subjek lain yang tidak menjadi subjek utama penelitian seperti orang yang dekat dengan subjek. Selanjutnya hasil analisa data dideskripsikan dalam pembahasan.

\section{B. MEDIA SOSIAL DAN PENGARUHNYA}

Media sosial adalah sebuah media online dimana para penggunanya dapat dengan mudah berpartisipasi. Berpartisipasi dalam arti seseorang akan dengan mudah berbagi informasi, menciptakan konten atau isi yang ingin disampaikan kepada orang lain, memberi komentar terhadap masukan yang diterimanya dan seterusnya. Semua dapat dilakukan dengan cepat dan tak terbatas. 4

Pada dasarnya media sosial merupakan perkembangan mutakhir dari teknologi-teknologi web baru berbasis internet, yang memudahkan semua orang untuk dapat berkomunikasi, berpartisipasi, saling berbagi dan membentuk sebuah jaringan secara online, sehingga dapat menyebarluaskan konten mereka sendiri. Post di blog, twett, atau video youtube dapat diproduksi

4 Devita Maulida Choir Uma, "Jurnal Komunikasi Media Sosial dan Perkembangan Fashion Hijab", (Surakarta:Sebelas Maret), 2014,h.8-9

Media sosial dan pengaruhnya terhadap.... 
dan dapat dilihat secara langsung oleh jutaan orang secara gratis. ${ }^{5}$

Menurut Kaplan dan Haenlein ada enam jenis media sosial:

a) Proyek kolaborasi

Website mengijinkan usernya untuk dapat mengubah, menambah, ataupun me-remove konten-konten yang ada di website ini, Contohnya Wikipedia.

b) Blog dan microblog

User lebih bebas dalam mengekspresikan sesuatu di blog ini seperti curhat ataupun mengkritik kebijkan pemerintah, Contohnya twitter.

c) Konten

Para user dari pengguna website ini saling mengshare konten-konten media, baik seperti video, ebook, gambar, dan lain-lain, Contohnya youtube.

d) Situs jejaring sosial Aplikasi yang mengijinkan user untuk dapat terhubung dengan cara membuat informasi pribadi sehingga dapat terhubung dengan orang lain. Informasi pribadi itu bisa seperti foto-foto, Contohnya facebook.

e) Virtual game world

Dunia virtual, dimana mengreplikasikan lingkungan 3D, dimana user bisa muncul dalam bentuk avatar-avatar yang diinginkan serta berinteraksi dengan orang lain selayaknya di dunia nyata, Contohnya game online.

f) Virtual social world

Dunia virtual yang dimana penggunanya merasa hidup di dunia virtual, sama seperti virtual game world, berinteraksi dengan yang lain. Namun,

5 Novia Ika Setyani, "Penggunaan Media Sosial Sebagai Sarana Komunikasi Bagi Komunitas", (Universitas Sebelas Maret, 2013), h. 6

Media sosial dan pengaruhnya terhadap.... 
virtual social world lebih bebas dan lebih kearah kehidupan, contohnya second life. ${ }^{6}$

Media sosial dapat dengan mudah sebagai media untuk mengekspresikan sesuatu yang berupa informasi pribadi yang mampu berinteraksi dengan orang lain selain itu media sosial juga mampu mereplikasikan lingkungan 3D berupa Game Online.

Media sosial memiliki beberapa pengaruh. Berikut pengaruh media sosial dalam beberapa aspek:

a) Individu; pengguna new media akan mendapatkan pengaruh besar jika menggunakannya dengan intensitas yang tinggi. Di satu sisi, pengguna bisa mengekspresikan segala idea tau gagasan melalui layanan-layanan yang dapat digunakan tanpa ada batasan. Namun disisi lain, seorang bisa menjadi individualis jika menggunakan internet dengan intesitas yang tinggi tanpa bersosialisasi di dunia nyata.

b) Ekonomi; new media menunjang perkembangan ekonomi melalui e-commerce atau komersial elektronik. New media sangat memungkinkan adanya ruang pemasaran dan marketing.

c) Politik; internet telah memunculkan istilah baru yakni electronic democracy. Website dapat digunakan untuk menyampaikan ide-ide dari para politikus, kepengurusan dan adanya ruang diskusi terbukadari bawah keatas dan sebaliknya dari atas ke bawah juga. Ruang diskusi inilah yang memberikan nilai demokratis dalam komunikasi politik.

d) Perubahan sosio-kultural; new media telah merubah banyak dari bentuk komunikasi yang dilakukan manusia selama ini. Perubahan pola komunikasi ini

6 Risna Apriyani," Pengaruh Media Sosial Facebook Pada Siswa Kelas Ix Dimadrasah Tsanawiyah Raudhatul Mu'allimin Islamiyah Darul Abror Bekasi, Skripsi di Jakarta: Universitas Islam Negeri Syarif Hidayatullah , 2014. h.17.

Media sosial dan pengaruhnya terhadap.... 
juga dapat mempengaruhi perubahan pada pola interaksi masyarakat yang beralih dari bentuk nyata (fisik) menjadi maya (digital). ${ }^{7}$

Di sisi lain, media baru bersifat imparsial. Kontenkonten yang ada dalam media baru tidak berpihak pada siapapun dan tidak dikuasai oleh segelintir orang saja. Karena itulah media baru seringkali disebut sebagai media yang sangat demokratis, karena kapitalisasi media tidak berlaku lagi. Setiap orang dapat menjadi produsen dan konsumen secara bersamaan dan setiap pengguna dapat berlaku aktif di sana. ${ }^{8}$

\section{AKHLAK}

Pada hakikatnya khuluq (budi pekerti) atau akhlak ialah suatu kondisi atau sifat yang telah meresap dalam jiwa dan menjadi kepribadian. Dari sini tibulah berbagai macam perbuatan dengan cara spontan tanpa dibuatbuat dan tanpa memerlukan pikiran.

Berbicara masalah akhlak maka tidak bisa lepas dari dua sifat yang selalu bertentangan tetapi selalu terjadi dan menghiasi semua perilaku manusia, yakni masalah baik dan buruk. ${ }^{9}$ Karena ini pula maka secara umum akhlak itu bisa berkategori baik (akhlaq mahmudah) dan bisa berkategori buruk (akhlaq madzmumah).

D. PENGGUNAAN MEDIA SOSIAL OLEH MAHASISWA DI PERGURUAN TINGGI AGAMA KOTA METRO.

Media sosial memang suatu hal yang wajib dimiliki oleh seorang mahasiswa, bahkan seorang mahasiswa

${ }^{7}$ Novia Ika Setyani, “Penggunaan Media., h. 9-10.

${ }^{8}$ Elisabeth Shinta/Riris Loisa,"Peran Media Sosial Facebook dalam Komunitas Kaum Lesbi Di Kota Tua",(universitas Tarumanagara),vol.3, No.2, 2011,h.37

9 Abuddin Nata, Akhlak Tasawuf, (Jakarta:Rajawali Pers, 2012), cet II, h.8.

Media sosial dan pengaruhnya terhadap.... 
memiiki lebih dari satu media sosial. Media sosial yang dimaksud dalam penelitian ini adalah media berbasis online yang di dalamnya para penggunanya bisa dengan mudah berpartisipasi, berbagi, dan saling berkomunikasi. Blog, jejaring sosial dan wiki merupakan bentuk media sosial yang umumnya digunakan oleh masyarakat di seluruh dunia.

Hampir seluruh mahasiswa di IAIN Metro, Universitas MuhammadiyahMetro dan IAIM NU Metro mengerti dan pengguna aktif media sosial khususnya untuk jejaring sosial. Tidak diragukan lagi bahwasanya media sosial sudah tidak asing lagi bagi mereka bahkan satu orang mahasiswa dapat memiliki dua bahkan lebih media sosial.

Media sosial merupakan hal sangatlah penting dan suatu keharusan untuk memilikinya. Pembelajaran di kampus juga sering kali mengharuskan mahasiswa untuk memiliki jejaring sosial maupun blog10.

Ada beberapa tugas kuliah yang mengharuskan mahawiswa mengupload tugas ke blog atau sekedar dikirim kepada dosen melalui surel maupun jejaring sosial. Hal ini tentu sangat menyulitkan mahasiswa bila mahasiswa tidak memiliki akun media sosial.

Menurut Leni, memiliki media sosial hanya untuk menyesuaikan perkembangan zaman. Dan apabila tidak memiliki media sosial akan menemui kendala dalam mencari informasi. ${ }^{11}$

Dari pendapat tersebut secara tidak langsung mereka mengatakan bahwa mempunyai media sosial itu penting, hanya saja ada berbagai alasan berbeda yang mereka gunakan untuk mengungkapkannya.

10 Wawancara dengan Agus, Mahasiswa Jurusan Teknik Sipil Universitas Muhammadiyah Metro Pada 20 Februari 2017.

11 Wawancara dengan Leni Aulia, Mahasiswa Jurusan Tarbiyah Institut Agama Islam Ma'arif (IAIM) NU Metro Pada 16 Februari 2017.

Media sosial dan pengaruhnya terhadap.... 
Dari jumlah mahasiswa yang menjadi sample, para mahasiswa mengatakan bahwa mereka memiliki handphone untuk membuka media sosial dan membawanya kekampus. Para mahasiswa mengatakan, handphone adalah alat komunikasi yang sangat praktis dan modern sehingga mereka dapat mengakses media sosial disela-sela perkuliahan. Sejak kapan para mahasiswa dapat leluasa mengakses media sosial saat perkuliahan berlangsung. Mengingat tugas dan kewajiban mahasiswa adalah belajar demi merain citacita. Ada beberapa mahasiswa yang bereaksi berlebihan, seperti bingung sendiri, gelisah, bahkan merasa sepi apabila mereka tidak membuka media sosial dan mengaksesnya satu hari saja. Namun ada juga mahasiswa yang menanggapinya biasa saja. Selain itu mahasiswa juga memanfaatkan media sosial sebagai sarana untuk mencari data. 12

Pemanfaatan media sosial bagi mahasiswa sangat beragam seperti untuk berkomunikasi dengan temanteman dan melihat informasi yang berkembang saat ini.

\section{E. PENGARUH MEDIA SOSIAL TERHADAP AKHLAK MAHASISWA DI KOTA METRO}

Pengaruh adalah suatu daya yang ada atau timbul dari sesuatu (orang, benda) yang ikut membentuk watak, kepercayaan, atau perbuatan seseorang. Media sosial sangat berpengaruh terhadap kehidupan sehari-hari para mahasiswa terutama mereka yang memiliki usaha yang memanfaatkan media sosial. Namun di dalam kemudahan itu juga terdapat pengaruh positif serta negatif.

Salah satu pengaruh positif media sosial adalah sebagai ajang memperbanyak teman maupun relasi bisnis dengan mudah. Media sosial juga dapat

12 Wawancara dengan Yudha, Mahasiswa Jurusan Ekonomi Syari'ah Institut Agama Islam Negeri (IAIN) Metro Pada 20 Februari 2017.

Media sosial dan pengaruhnya terhadap.... 
dipergunakan sebagai media komunikasi kita dengan orang-orang, baik dalam maupun luar negeri tempat mencari informasi, banyak juga istansi pencari berita yang menggunakan media sosial sebagai media penyebarannya.

Yudha berpendapat bahwa media sosial sangatlah penting dan berperan bagi kehidupan sehari-hari. Bahkan, akan sulit jika tidak ada media sosial. ${ }^{13}$ Begitu halnya dengan Leni yang menyatakan bahwa media sosial merupakan kebutuhan utama bagi mahasiswa. ${ }^{14}$

Kehadiran media sosial membuat para mahasiswa dibuat latah untuk memilikinya. Pengaruh yang ditimbulkan media sosial tersebut juga cukup besar baik itu pengaruh positif maupun pengaruh negatif. Berikut ini beberapa pengaruh positif dan negatif media sosial:

a. Pengaruh positif media sosial bagi mahasiwa

1) Mempermudah kegiatan belajar, karena dapat digunakan sebagai sarana untuk berdiskusi dengan teman tentang tugas (mencari informasi) serta membaginya di media sosial. ${ }^{15}$

2) Mencari dan menambah teman, karena media sosial dapat membantu kita untuk bertemu kembali dengan teman lama maupun teman yang kita kenal melalui media sosial. 16

13 Wawancara dengan Yudha, Mahasiswa Jurusan Ekonomi Syari'ah Institut Agama Islam Negeri (IAIN) Metro Pada 20 Februari 2017.

14 Wawancara dengan Leni Aulia, Mahasiswa Jurusan Tarbiyah Institut Agama Islam Ma'arif (IAIM) NU Metro Pada 16 Februari 2017.

15 Wawancara dengan Susanti , Mahasiswa Jurusan Ekonomi Syari'ah Institut Agama Islam Negeri (IAIN) Metro Pada 20 Februari 2017. 
3) Menghilangkan kepenatan. Misalnya dengan mengomentari status orang lain yang terkadang lucu dan mengelitik, bermain game, mencari data , dan lain sebagainya. ${ }^{17}$

b. Pengaruh negatif media sosial bagi mahasiswa

1) Berkurangnya waktu belajar, terlalu lama mengakses media sosial akan mengurangi waktu jatah belajar karena begitu banyak konten yang disajikan oleh media sosial sehingga mereka lupa sudah berapa lama mereka mengakses media sosial tersebut. ${ }^{18}$

2) Mengganggu konsentrasi belajar saat di kampus dan tidak memperhatikan apa yang sedang di sampaikan oleh dosen yang sedang menyampaikan materi sehingga mereka tidak akan paham tentang materinya. ${ }^{19}$

3) Merusak moral mahasiswa. Banyaknya waktu yang digunakan untuk mengakses media sosial tersebut sehingga membuat mereka ingin membuka semua konten yang terdapat pada media sosial sehingga tidak menutup kemungkinan mereka juga berkeinginan

16 Wawancara dengan Leni Aulia, Mahasiswa Jurusan Tarbiyah Institut Agama Islam Ma'arif (IAIM) NU Metro Pada 16 Februari 2017.

17 Wawancara dengan Nitha astuti, Mahasiswa Jurusan Pendidikan Ekonomi Universitas Muhammadiyah Metro Pada 20 Februari 2017.

18 Wawancara dengan Leni Aulia, Mahasiswa Jurusan Tarbiyah Institut Agama Islam Ma' arif (IAIM) NU Metro Pada 16 Februari 2017.

19 Wawancara dengan Agus, Mahasiswa Jurusan Teknik Sipil Universitas Muhammadiyah Metro Pada 20 Februari 2017.

Media sosial dan pengaruhnya terhadap.... 
untuk membuka konten-konten yang dapat mempengaruhi moral mereka. ${ }^{20}$

4) Menghabiskan uang jajan, menurunnya komunikasi antar mahasiswa, mengganggu kesehatan $^{21}$

Dari pengaruh-pengaruh yang ditimbulkan oleh media sosial pengaruh negatif lebih mendominan dibandingkan dengan pengaruh positif dari media sosial. Dari penelitian ini menunjukan bahwa media sosial mempengaruhi akhlak mahasiswa baik kepada hal positif maupun negatif. Yang mana jika semakin banyak mahasiswa menggunakan media sosial terhadap hal-hal yang kurang berguna maka akhlak mahasiswa akan negatif.

Misalnya semakin asyik mahasiswa bermain media sosial maka semakin besar kemungkinan siswa untuk menunda-nunda perintah Allah SWT, jauh terhadap sunnah Rasul, menunda-nunda tugas kampus dan tidak peduli dengan orang sekitarnya. Tetapi jika seorang mahasiswa dapat mengontrol dalam penggunaan media sosial maka akhlak mahasiswa akan positif misalnya media sosial digunakannya untuk halhal edukasi yang memotivasi dirinya untuk selalu bertakwa kepada Allah, mencintai Rosul dan peduli terhadap alam sekitar.

Selain media sosial dapat mempengaruhi akhlak media sosial juga dapat mempengaruhi kesehatan, menurunkan angka komunikasi antar mahasiswa dan lingkungan sekitar.

Pengaruh negatif yang ditimbulkan oleh adanya media sosial salah satunya adalah munculnya tindak

20 Wawancara dengan Yudha, Mahasiswa Jurusan Ekonomi Syari'ah Institut Agama Islam Negeri (IAIN) Metro Pada 20 Februari 2017.

21 Wawancara dengan Agus, Mahasiswa Jurusan Teknik Sipil Universitas Muhammadiyah Metro Pada 20 Februari 2017.

Media sosial dan pengaruhnya terhadap.... 
kejahatan. Media sosial juga dapat menimbulkan candu yang dapat mengakibatkan sifat penggunanya menjadi autis atau lebih menutup diri pada kehidupan sekitar. Media sosial juga dapat mempengaruhi akhlak seorang pelajar, siswa, maupun mahasiswa dalam proses belajar mengajar. ${ }^{22}$

Jadi lebih baik media sosial digunakan sebagaimana mestinya pada waktu dan tempat yang tepat. Jangan sampai kita terpengaruh kepada hal negatif yang ditimbulkan oleh media sosial. Buatlah media sosial sebagai suatu produk perkembangan zaman yang mampu membuat kita menjadi terdepan dan akhlak kita menjadi lebih baik karena banyak pengetahuan formal maupun non formal yang bisa kita dapatkan dari media sosial.

\section{F. KESIMPULAN}

Tingginya intensitas pengguna media sosial (jejaring sosial) pada mahasiswa di Kota Metro berpengaruh terhadap akhlak mahasiswa, baik pengaruh psitif maupun negatif. Oleh sebab itu, mahasiswa harus bersikap selektif dan bijak agar memanfaatkan media sosial hanya untuk hal-hal yang positif. Mahasiswa juga harus mencegah pengaruh negatif penggunaan media sosial seperti sikap kurang bersosialisasi terhadap lingkungan dan menurunya sifat menghargai terhadap seseorang yang berdampak negatif terhadap akhlaknya.

22 Wawancara dengan Susanti, Mahasiswa Jurusan Ekonomi Syari'ah Institut Agama Islam Negeri (IAIN) Metro Pada 20 Februari 2017. 


\section{DAFTAR PUSTAKA}

Abdullah Sulong dan Mawaddah Abdullah, Pengaruh Media Elektronik Terhadap Keruntuhan Akhlak Pelajar, Universiti Teknologi Malaysia, h. 2. Diakses Melalui Laman: http://eprints.utm.my/10835/1/Pengaruh_Media_Ele ktronik_Terhadap_Keruntuhan_Akhlak_Pelajar.pdf Abuddin Nata,Akhlak Tasawuf, (Jakarta:Rajawali pers),cet II,2012,.

Devita Maulida Choir Uma, "Jurnal Komunikasi Media Sosial dan Perkembangan Fashion Hijab", Surakarta:Sebelas Maret, 2014,

Elisabeth shinta/Riris Loisa,"Peran Media Sosial Facebook dalam Komunitas Kaum Lesbi Di Kota Tua", Universitas Tarumanagara, Vol. 3, No. 2, 2011.

Lina Aprilia, Pengaruh Internet Terhadap Akhlak Siswa Kelas XI SMAN 1 Jatisrono, Fakultas Agama Islam Universitas Muhammadiyah Surakarta; 2014.

M. Yatimin Abdullah, Study Akhlak dalam Perspektif AlQur'an, Jakarta: Amzah, cet.I, 2007.

Muhammad Hasan Tholhaha, Islam dan Masalah Sumber Daya Alam, (Jakarta Selatan : Lantabora Press, 2004.

Novia Ika Setyani, "Jurnal Komunikasi Penggunaan Media Sosial Sebagai Sarana Komunikasi Bagi Komunitas", Universitas Sebelas Maret, 2013.

Ramadhansyah, Pertumbuhan Sosial Media, (2012),h.8 dikutip dari Jurnal Komunikasi, Novia Ika Setyani, "Penggunaan Media Sosial Sebagai Sarana Komunikasi Bagi Komunitas", (Universitas Sebelas Maret, 2013

Risna apriyani, Pengaruh Media Sosial Facebook Pada Siswa Kelas Ix Dimadrasah Tsanawiyah Raudhatul Mu'allimin Islamiyah Darul Abror Bekasi, Skripsi di Jakarta: Universitas Islam Negeri Syarif hidayatullah , 2014. 